\title{
Noncanonical Ion Channel Behaviour in Pain
}

\author{
Cosmin I. Ciotu ${ }^{1,+}+\mathbb{D}$, Christoforos Tsantoulas ${ }^{2,+}$, Jannis Meents ${ }^{3,+}{ }^{\oplus}$, Angelika Lampert ${ }^{3}$, \\ Stephen B. McMahon ${ }^{2}\left(\mathbb{D}\right.$, Andreas Ludwig ${ }^{4}$ and Michael J.M. Fischer ${ }^{1, *(\mathbb{D}}$ \\ 1 Center for Physiology and Pharmacology, Medical University of Vienna, 1090 Vienna, Austria \\ 2 Wolfson Centre for Age-Related Diseases, King's College London, London SE1 1UR, UK \\ 3 Institute of Physiology, University Hospital RWTH Aachen, 52074 Aachen, Germany \\ 4 Institute of Experimental and Clinical Pharmacology and Toxicology, Friedrich-Alexander-Universität \\ Erlangen-Nürnberg, 91054 Erlangen, Germany \\ * Correspondence: michael.jm.fischer@meduniwien.ac.at; Tel.: +43-1-40160-31410 \\ + These authors contributed equally to this work.
}

Received: 7 August 2019; Accepted: 12 September 2019; Published: 15 September 2019

\begin{abstract}
Ion channels contribute fundamental properties to cell membranes. Although highly diverse in conductivity, structure, location, and function, many of them can be regulated by common mechanisms, such as voltage or (de-)phosphorylation. Primarily considering ion channels involved in the nociceptive system, this review covers more novel and less known features. Accordingly, we outline noncanonical operation of voltage-gated sodium, potassium, transient receptor potential (TRP), and hyperpolarization-activated cyclic nucleotide ( $\mathrm{HCN})$-gated channels. Noncanonical features discussed include properties as a memory for prior voltage and chemical exposure, alternative ion conduction pathways, cluster formation, and silent subunits. Complementary to this main focus, the intention is also to transfer knowledge between fields, which become inevitably more separate due to their size.
\end{abstract}

Keywords: pharmacology; drug development; sodium channel; potassium channel; TRP channel; $\mathrm{HCN}$ channel

\section{Overview}

The main aim of this review is to illustrate unexpected behaviour of ion channels, which might cross-pollinate advances between fields. To at least partly fulfil this aim, we restricted coverage to the pain field and the subsections are written by authors with a focus on the respective ion channel families. We consider as canonical any feature of an ion channel pore-forming protein, which can allow the flow of ions across membranes [1]. Although not universal, common features include regulation of the permeation (gating) by ligands and voltage; preference or selectivity for some ions over others; interaction with other cytoplasmic or membrane proteins; trafficking between the plasma membrane and reserve pools; heteromerisation of the channels; modulation by intracellular cascades e.g., by a change of phosphorylation state; and a change of expression levels, e.g., in inflammatory conditions. Less common and more on the line between canonical and noncanonical are features such as interaction with phospholipids or accessory subunits.

\section{Sodium Channels}

Voltage-gated sodium channels (Navs) are responsible for the generation of action potentials in most excitable cells, such as neurons and muscle cells. Ten different isoforms have been described in mammals (Nav1.1-1.9 and Nax), which vary in tissue expression and electrophysiological properties [2,3]. Generally, Navs are highly voltage sensitive and open in response to small membrane depolarisations. They are selective for the conduction of sodium ions, thus amplifying membrane 
depolarisation and initiating action potentials. For the study and treatment of pain, the subtypes Nav1.7, Nav1.8, and Nav1.9, mostly expressed in peripheral sensory neurons, have received large interest over recent years considering that mutations in these channel isoforms can lead to a variety of pain syndromes in patients [4,5]. Well-described canonical features of Nav channel activity comprise voltage-dependent gating and fast inactivation during membrane depolarisation as well as channel deactivation upon cell membrane repolarisation $[2,6,7]$. Of note in this respect are the recently published 3-D crystal structures of different Nav isoforms that have shed a new light on these well-known functions [8-11]. There are, however, a number of rather unexpected and less well-understood channel functions that will be discussed in the following. Some of these have already been reviewed in a similar context by Barbosa and Cummins [12].

In addition to fast inactivation, which occurs within milliseconds after channel opening, Navs can also undergo slow inactivation, a process that takes place on a time scale of seconds to minutes. Under experimental conditions, this process can be observed during prolonged depolarisations (e.g., 30-60 s). Physiologically, slow inactivation is believed to take place during high-frequency firing, also serving to modulate it. Slow inactivation in Navs has been known for several decades $[13,14]$. Slow inactivation is different depending on Nav channel isoform, and the exact molecular determinants for slow inactivation are difficult to pinpoint as many positions and residues have been described that seem to affect slow inactivation. Generally, the process of slow inactivation in Navs bears similarities to the C-type inactivation of potassium channels and involves the channel pore [15]. Especially a ring of four negatively charged amino acids directly above the selectivity filter (E409, E764, D1248, and D1539 in hNav1.4 [9]) seems to be involved in this process [16]. However, many other residues both inside and outside the channel pore have been implicated in slow inactivation (reviewed in References $[13,14])$. With regards to nociception, slow inactivation has been found to be modulated by different mutations in Nav1.7 that cause the chronic pain syndrome erythromelalgia [17-29] (reviewed in References $[12,30])$. Slow inactivation in peripheral Navs seems to be enhanced by cold temperatures, with the exception of Nav1.8, which inactivates cold-independently and thus mediates cold nociception in mice [31].

Slow inactivation can be regarded as a sort of negative hysteresis, i.e., Nav channels "remember" a previous prolonged or high-frequency stimulation and, as a result, remain inactive. In other ion channels, such as transient receptor potential and potassium channels, different forms of hysteresis have been described, including an increase in conduction or sensitivity upon prolonged or repeated stimulation (see below and in Reference [32]. However, our group has failed to show changes in voltage dependence of activation of Nav1.7 after a series of depolarizing pre-pulses, thus questioning the role of positive hysteresis in Nav1.7 [33].

According to the canonical view, Nav channels inactivate milliseconds after opening and remain impassive to sodium flux until the cell membrane has repolarised and the channel has returned to its resting state. However, an unusual Nav current, termed resurgent current, has been described to occur during membrane repolarisation. Since their first description in the late ' 90 s in cerebellar Purkinje neurons [34], resurgent currents have become highly investigated and are believed to modulate high-frequency action-potential firing in different types of neurons, including nociceptors [35]. The molecular process of resurgent currents consists of an open channel block by a positively charged intracellular blocking particle, which occludes the channel pore before fast inactivation occurs. During membrane repolarisation, this particle is released from the channel pore due to its positive charge, thus leading to a very brief inward sodium current before the channel inactivates [35,36]. The most likely candidate for the open channel blocking particle is the C-terminal end of the Nav $\beta 4$ subunit [35,37]. Peripheral sensory neurons express fast and slow resurgent currents, mainly mediated by Nav1.6, Nav1.2, and potentially Nav1.8 [38-40]. Nav1.7 has also been shown to produce resurgent currents of small amplitudes. However, mutations in Nav1.7 that cause the chronic pain phenotype paroxysmal extreme pain disorder (PEPD) enhance resurgent currents in this Nav subtype, whereas mutations leading to erythromelalgia do not $[29,41]$. Interestingly, there seems to be a direct correlation between 
resurgent current generation and slow inactivation in Nav1.6 and Nav1.7: enhanced slow inactivation impairs resurgent currents and vice-versa [29].

Local anaesthetics can be a useful tool for quick and localized pain treatment. These drugs have been shown to bind inside the central cavity of the channel pore [42-44]. Recent findings in prokaryotic and mammalian Nav channels have substantiated earlier reports, which suggested that entry of local anaesthetics into the central cavity can be mediated via the lipid phase of the cell membrane [45]. The recently published 3-D crystal structures as well as earlier models show side fenestrations of the channel pore, which are large enough to be permeated by small molecules, such as local anaesthetics $[9,10,46-49]$. This may have important implications for the future development of Nav channel blocking compounds.

Several naturally occurring mutations in Nav1.2, Nav1.4, and Nav1.5 have been reported to conduct so-called gating pore (or omega) currents. These currents originate from mutations of gating charge residues in the S4 voltage sensor, leading to an alternative ion permeation pathway across the membrane [50-54] (reviewed in Reference [55]). Whereas such gating pore currents have not yet, to our knowledge, been investigated in nociceptive Nav channel isoforms, it might still be worthwhile to check for such currents, especially in Nav1.6-Nav1.9, as leak currents through these channels would almost certainly affect nociceptor excitability and pain perception.

\section{Potassium Channels}

Potassium channels are the most populous, diverse, and widely distributed ion channel superfamily. Once regarded as "innocent bystanders" that could nevertheless be pharmacologically exploited to counteract neuronal hyperexcitability rising from maladaptive activity of other ion channels, potassium channels are increasingly viewed as key players that can directly promote pain pathogenesis [56]. Indeed, an ever-growing number of studies report causative links between reduced function of specific potassium channel subunits and development of neuronal hyperexcitability and pain sensation [57]. Furthermore, in not electrically excitable cells, potassium channels participate in several neurophysiological processes that are independent of ion conduction, such as proliferation, migration, and exocytosis, and the mechanisms governing these noncanonical functions may also be of relevance to pain syndromes [58-60].

The best studied group, voltage-gated potassium channels $(\mathrm{Kv})$, comprises 40 members which assemble as homo- or hetero-tetramers and mediate a hyperpolarising $\mathrm{K}^{+}$efflux that limits neuronal excitability by opposing action-potential generation. Membrane depolarisation triggers $\mathrm{Kv}$ opening via movement of the voltage sensor, which is coupled through a 15aa helical S4-S5 linker to the channel pore [61]. Recent work, however, in Drosophila's Shaker potassium channels (closely related to human Kv1 channels) identified an additional electromechanical coupling between residues of transmembrane domains S4 and S5 which facilitate movement of the helices in a "rack-and-pinion" fashion [62]. This noncanonical mechanism is a good candidate to explain pore opening in channels like hERG (Kv11.1), which contain a short S4-S5 linker, expendable for voltage-gating [63,64].

The traditional view of $\mathrm{Kv}$ opening exclusively gated by voltage was challenged by Hao et al., who demonstrated that Kv1.1 is a bona fide mechanoreceptor in sensory neurons [65]. In thorough experiments, it was shown that a variety of mechanical manipulations such as piezo-electrically driven force, membrane stretching, and hypoosmotic shock directly activate Kv1.1 channels to mediate a mechanosusceptive current, dubbed $\mathrm{I}_{\text {Kmech. }}$. Mechanistically, generation of $\mathrm{I}_{\mathrm{Kmech}}$ results from a change in the voltage dependence of the open probability, favouring the open conformation of the channel. Traditional mechanotransducers use a mechanical sensor linked to cytoskeletal elements to convert membrane tension energy into conformation changes. In contrast, Kv1.1 mechanoactivation may depend on inherent properties of the voltage sensor because mechanosensitivity is retained in excised patches of DRG neurons [65]. The authors postulated that the local membrane distortion induced by applied forces alters the energetic stability of the voltage-sensing machinery by physical movement of charges within the channel. Whatever the precise mechanism, Kv1.1 activation by 
mechanical stimulation can-because it reduces neuronal excitability-tune sensory neuron excitability by opposing excitatory influences of mechanosensitive cation channels. The net outcome of this process depends on the exact ionic channel complement of the neuron; in C-high threshold mechanoreceptors which mediate slowly adapting mechanosensitive cation currents [66], $\mathrm{I}_{\text {Kmech }}$ opposes depolarisation and increases mechanical thresholds. In contrast, in A $\beta$ mechanoreceptors which encode rapidly adapting mechanosensitive currents, $\mathrm{I}_{\mathrm{Kmech}}$ is not engaged sufficiently to influence firing thresholds but can nevertheless regulate firing rates. This elaborate control of mechanosensitivity by a $\mathrm{Kv}$ channel is a novel mechanism of mechanosensation, and inhibition of this pathway due to injury or inflammation could promote mechanically induced pain. Consistent with this, blocking Kv1.1 activity in mice either genetically or pharmacologically triggers mechanical hypersensitivity, without affecting heat pain responses [65].

The closely related member Kv1.2 also stands out because its function is subject to epigenetic silencing by G9a (histone-lysine N-methyltransferase 2) [67]. Neuropathic injury induces the Myeloid Zinc Finger 1 transcription factor, which in turn upregulates a long noncoding antisense RNA which attenuates Kv1.2 expression and activity, leading to hyperexcitability and pain sensitivity in rodents. Blocking induction of the antisense RNA spares Kv1.2 expression and is protective against pain [68]. This and other emerging pathways regulating $\mathrm{Kv}$-dependent excitability via epigenetic modifications [69] might constitute a dynamic mechanism which shapes neuronal activity in development and disease [70,71]; the applicability of this theme in pain pathology remains to be further established but could critically inform gene therapy approaches in the near future.

$\mathrm{Kv} 2.1$ is another interesting channel as it features unique subcellular localisation, regulation by silent subunits, and nonconducting functions. Being a high-threshold channel with characteristically slow kinetics, Kv2.1 becomes particularly important during prolonged stimulation, like that encountered in central neurons during seizures [72,73], or in peripheral nociceptors during spontaneous firing. Accordingly, inhibiting Kv2.1 currents in DRG neurons allows higher firing rates during sustained input [74], while Kv2.1 knockout in the CNS results in neuronal hyperexcitability reminiscent of epilepsy [72]. It therefore appears that Kv2.1 acts as a resistor that filters elevated neuronal firing and is compromised in syndromes linked to neuronal hyperexcitability, including chronic pain. Kv2.1 is downregulated in damaged sensory neurons thus promoting hyperexcitability [74], but as Kv2.1 levels are not completely abolished, this may be exploitable for pharmacological enhancement with $\mathrm{Kv}$ openers. Constituent reduction of Kv2.1 activity can also occur via mutations in the KNCB1 gene; missense variants located within the pore domain result in loss of $\mathrm{K}^{+}$selectivity and generation of a depolarizing inward sodium current at negative voltages [75] or even loss of voltage dependence, causing Kv2.1 to remain tonically open [73]. It will be interesting to investigate whether similar Kv2.1 mutations are linked to human pain channelopathies.

$\mathrm{Kv} 2.1$ is robustly regulated by members of the Kv5, Kv6, Kv8, and $\mathrm{Kv} 9$ families, which comprise the so-called "silent subunits" (KvS). These enigmatic proteins are incapable of conducting currents on their own but can form functional tetramers with Kv2.1, substantially altering the biophysical properties of the channel [76]. For instance, association of Kv2.1 with any of Kv5.1, Kv6.1, Kv9.1, or Kv9.3 hyperpolarises the voltage dependence of inactivation in pyramidal neurons, while Kv2.1/Kv5.1 exhibits accelerated rates of (open-state) inactivation and slower closing rates upon repolarization (deactivation) [77]. Mechanistically, these modulatory effects can be mediated by direct changes in the gating mechanism or indirectly by promoting $\mathrm{Ca}^{2+} /$ calmodulin-dependent dephosphorylation $[77,78]$. It is becoming increasingly evident that heteromerization of $\mathrm{Kv} 2.1$ with different $\mathrm{KvS}$ endows neurons with functional diversity that is often essential for normal physiology. For example, mammalian photoreceptors depend on Kv2.1/Kv8.2 channels to mediate transient hyperpolarizing overshoots of the membrane potential [79,80] and Kv8.2 mutations cause a cone dystrophy disorder [81]. Kv6.1, Kv8.1, and Kv8.2 have also been implicated in hyperexcitability of hippocampal neurons relevant to epilepsy [82-84]. 
KvS have also been implicated in chronic pain. Kv9.1 co-localises with Kv2.1 in myelinated sensory neurons that become hyperexcitable following nerve damage. Injury-induced Kv9.1 downregulation decreases Kv2.1 activity and enhances excitability, including spontaneous and evoked firing, and triggers pain hypersensitivity in rodents [85]. Consistent with this, deletion of the KCNS1 gene encoding Kv9.1 in mice results in basal and neuropathic pain sensitivity [86]. Kv2.1, but not Kv9.1, is also expressed in small nociceptors [74], but the composition of the native tetramers is not known. Since Kv2.1 conduction is sculpted by the modulatory influence of silent subunits, it is plausible that different $\mathrm{Kv} 2.1 / \mathrm{KvS}$ combinations and stoichiometry can fine-tune excitability in distinct classes of sensory neurons. For example, Kv9.3 hyperpolarises the voltage dependence of $\mathrm{Kv} 2$ inactivation more substantially than $\mathrm{Kv} 9.1[78,87,88]$ and, even for a given $\mathrm{KvS}$, the physiological impact is predicted to depend on whether firing is limited by the inactivation of inward currents [88]. The importance of Kv2.1 modulation by Kv9.1 in nociception is further underscored by the identification of two SNPs in the human Kv9.1 gene, which predisposes to the development of chronic pain [89]. Similarly, mutations in Kv6.4 may promote excitability of trigeminal neurons during migraine attacks [90] as well as pain during labor [91]. The role of KvS in pain is still poorly understood, and it may even include regulation of noncanonical Kv2.1 functions such as channel clustering and protein trafficking, as discussed below. Untangling this pathway could provide unique opportunities for pain treatments, which may prove advantageous compared to targeting the ubiquitously expressed Kv2.1 subunit.

A prime example of noncanonical $\mathrm{Kv}$ function is the formation of large clusters by Kv2.1 channels which localise to the neuronal membrane of the soma, proximal dendrites, and axon initial segment of CNS neurons [92]. In contrast to the active, diffused form of the channel, these micrometer-sized clusters are found to be primarily nonconductive $[93,94]$ and are dispersed in response to neuronal activity, glutamate-induced excitotoxicity, hypoxia, or second messengers $[95,96]$. Regulation of cluster formation was originally thought to fine-tune neuronal excitability by dynamic control of the active vs. inactive forms but recent evidence hints towards a nonconducting role for Kv2 clusters. Thus, Kv2.1 and $\mathrm{Kv} 2.2$ clusters play a structural role in the formation of plasma membrane-endoplasmic reticulum junctions which serve as trafficking hubs for recruitment of several proteins (e.g., voltage-activated $\mathrm{Ca}^{2+}$ channels, VAMPs, AKAPs, kinases, and syntaxin), important for many neurophysiological processes like trafficking, neurotransmitter release, $\mathrm{Ca}^{2+}$ homeostasis, and burst firing [97-101]. Such a role is consistent with the identification of three Kv2.1 mutations which cause neurodevelopmental disorders despite the fact that they do not alter Kv2.1 conductance per se [102]. While Kv2 cluster formation has not been confirmed in peripheral sensory neurons, it is plausible that similar mechanisms operate in the pain-signaling pathways and that disruption of normal $\mathrm{Kv} 2$ clustering due to inflammation or injury affects nociceptive excitability.

Two $\mathrm{P}$ (ore) domain potassium channels (K2Ps) are known for facilitating a passive and rapid $\mathrm{K}^{+}$ flow at a range of membrane potentials. This leak (also called background) outward conductance stabilises resting membrane potential, assists repolarisation, and even enables AP generation in the absence of classical Kv channels [103]. Surprisingly, however, additional voltage-dependent activation has been documented in some K2P channels despite the absence of a canonical voltage-sensing domain with a positively charged S4-helix for gating by depolarisation [104,105]. Instead, voltage sensitivity appears to derive from movement of three or four ions into the high electric field of the selectivity filter [106], which then acts to "gate" the movement of $\mathrm{K}^{+}$ions. Thus, in contrast to classical $\mathrm{Kv}$ channels where the properties of voltage sensing, activation, and inactivation can be mapped to distinct regions of the channel, K2Ps carry out these functions by employing different structural states of the selectivity filter. Moreover, many stimuli relevant to physiological functions such as $\mathrm{PIP}_{2}$, acidosis, and membrane stretch can switch off this voltage activation [107], limiting K2Ps to leak conductance by locking them open. Altogether, K2P channels are increasingly recognised as important modulators of polymodal pain perception. The best studied members TRAAK, TREK1, and TREK2 are mechano- and thermosensitive, albeit at different temperature ranges (TRAAK and TREK1, noxious temperatures; 
TREK2, moderate temperatures) [108-112]. Accordingly, deletion of these channels affects mechanical, heat, and oxaliplatin-induced cold sensitivity [108,109,112,113].

When covering atypical potassium channel function, a special mention should be made on inwardly rectifying potassium channels (Kir) which are mainly found in supporting cells such as glia. Kir channels are unique in that, at depolarised potentials, they preferentially mediate movement of $\mathrm{K}^{+}$ ions towards the inside of the cell in contrast to other potassium channels. The resulting inward currents help maintain resting membrane potentials and are therefore important in a number of physiological processes such as microglial activation during inflammation [114]. In addition, the buffering activity of Kir in nonneuronal cells prevents extracellular $\mathrm{K}^{+}$accumulation, which would cause action potential "short-circuiting" and could detrimentally impact neuronal excitability $[115,116]$. Several members of the seven Kir subfamilies (Kir1-Kir7) have been specifically implicated in pain modulation. Kir4.1 channels expressed in satellite glia cells of the trigeminal ganglion appear to be important for facial pain. Silencing Kir4.1 expression in rats to mimic the effect of nerve injury or inflammation induces hyperexcitability and facial pain behaviours $[117,118]$, while Kir4.1 knockout mice exhibit depolarised membrane potentials and inhibition of $K^{+}$uptake $[119,120]$. Members of the Kir3 family (also known as $\mathrm{G}$ protein-regulated inward rectifiers $\mathrm{K}^{+}$channels, GIRK) are crucial mediators of spinal analgesia because their coupling to $G$ proteins underlies analgesia conferred by endogenous and exogenous opioids [121,122]. Consistent with this, variations in the gene encoding GIRK2 are associated with pain phenotypes, as well as analgesic responses in humans [121-123]. Besides their established role in the CNS, GIRK2 expressed in sensory neurons may also contribute to peripheral antinociception induced by opioids [124].

Together, there is considerable interest in developing novel forms of analgesia by modulating $\mathrm{K}^{+}$ channel function, either correcting a primary pathology underpinning a pain state or nonspecifically reducing neuronal excitability. Much of the early interest focused on $\mathrm{Kv}$ channel openers, but more recent data suggests that drugs activating K2Ps may prove useful for a variety of pain symptoms [125]. Recently, a somewhat counterintuitive observation was that opening of ATP-sensitive potassium channels induces migraine attacks in migraineurs using a randomized, double-blind, placebo-controlled, crossover design [126]. The mechanism is not clear but might involve neuronal or nonneuronal processes, given the widespread distribution of these channels. It is worth noting that other $\mathrm{K}^{+}$channels have a much more restricted distribution to nociceptive neurons.

\section{TRP Channels}

Transient receptor potential (TRP) channels form a group of 28 ion channels (27 in humans) organized into 7 families TRPC (canonical), TRPM (melastatin), TRPV (vanilloid), TRPA (ankyrin), TRPML (mucolipin), TRPP (polycystic), and TRPN (no mechanoreceptor potential C) [127,128]. Members of this family continue to be among the most studied in the ion channel field, in particular for pain as their relevance for certain pathophysiological conditions and peripheral sensory perception prompts them as targets for therapeutic modulation [129-131]. Canonical features of this family would be weak voltage-dependence [132], conductance for cations including divalent cations [133], and frequently, channel-specific rectification [134]. Below, some unexpected channel behavior is discussed.

TRPM3 has been found to generate an unexpected conductance when a combination of agonists was applied, namely pregnenolone sulfate and clotrimazole (or sole application of the agonist CIM0216) $[135,136]$. This ion permeation pathway, that allows inward rectification driven by $\mathrm{Na}^{+}$, has been likened to the omega pore in classical voltage-gated cation channels; however, the latter has been uncovered in disease-inducing mutations, whereas in the case of TRMP3, it exists in the wild-type channel. Moreover, in the case of clinically relevant clotrimazole plasma levels, it is feasible that, at $37^{\circ} \mathrm{C}$, circulating levels of pregnenolone sulfate can open this alternative pore [135]. Further analysis of the voltage-sensing domain of TRPM3 by means of site-directed mutagenesis revealed a critical role of several amino acids in the voltage-sensing domain for the formation of 
this alternative ion-permeation pathway [136]. In other channel families, including potassium, sodium, and proton channels, channel mutations have also been shown to cause noncanonical pores, as discussed above $[51,137,138]$. Ultimately, such unexpected behaviour can contribute to a larger goal, understanding the gating and overall ion channel molecular mechanics.

The majority of TRP channels is outwardly rectifying, despite some exceptions such as TRPML1/2/3 [139] and TRPV5/6 [140]. In case the rectification is not dependent on divalent cations, causing asymmetry by an open channel block $[141,142]$, this is an intrinsic property of the channel. This property can be changed by a single helix-breaking amino acid, as shown for the TRPML3-A419P mutation [143].

Increasing response to continuous agonist exposure: TRPA1 stands out by being most sensitive to modification by electrophilic molecules, a feature which critically involves cysteine residues on the $\mathrm{N}$ terminus of the channel [144-147]. Irrespective of the mode of activation, a dilation of the pore has been described for TRPA1, a feature attributed only to a few ion channels, including TRPV1 [148]. This pore dilation has a time constant below $10 \mathrm{~s}[149,150]$. It should be mentioned that an alternative explanation to dilations of the pore has been proposed [151] (summarized in Reference [152]).

However, a slow but several-fold increase in conductance upon continuous agonist exposure with a much longer time course has been demonstrated [153]. These current increases can be better studied in the absence of calcium, as calcium influx causes a calcium-dependent desensitisation, and both mechanisms seem to balance each other. This allows continuous activation through TRPA1, where other channels show extensive tachyphylaxis or desensitisation. The mechanism is not PKA- or PKC-dependent. The topic has been further investigated using the noncovalent agonist carvacrol [154]. In contrast to the slow covalent action of TRPA1 by allyl isothiocyanate, the time constant for activation by carvacrol was $3.1 \mathrm{~s}$, which allowed for tracking the current faster. A similar agonist-induced current increase was detected, and the current observed after a previous exposure is picked up almost invariable to the period between stimuli. The time constant of agonist-induced sensitisation was $130 \mathrm{~s}$, which is well above all other described processes. Agonist exposure is required for this effect, as it could not be reproduced by opening the channel using voltage stimulation. Agonist-induced sensitisation occurred between covalent and non-covalent agonists, indicating a modification which is common to all agonists but upstream or independent of voltage-induced gating. However, a current through the channel was not required, as the exposure time-dependent current increase progresses when flux is inhibited by the additional presence of an antagonist. Similar to allyl isothiocyanate, a desensitisation was observed for saturating concentrations of carvacrol; the reason for this remaining unclear. The agonist-induced sensitisation was assumed to bring TRPA1 into a hypothesized state, which has a far left-shifted voltage dependence [154]. Inhibition of ATP-dependent mechanisms and membrane trafficking also did not affect the observation. TRPA1 has been investigated using long exposures mainly due to the slow onset required for the covalent agonists. This is not required for other channels; therefore, such protocols might simply not have been tested so far. It should be mentioned that a shift in concentration-dependent binding with prolonged agonist exposure has been reported in other receptors [155]; an "imprinting" by a lasting conformational change was hypothesized. For TRPA1, the change in receptor binding after prolonged exposure has not been investigated.

\section{HCN Channels}

Hyperpolarization-activated cyclic nucleotide-gated $(\mathrm{HCN})$ channels comprise a small family with four members, HCN1-HCN4 [156-160]. The channels are related to CNG and Kv channels [161-163] but are distinguished by several unique features. HCN channels are controlled by the membrane potential; however, in contrast to most other voltage-gated ion channels, hyperpolarization but not depolarization opens them. Second, the channels contain the GYG motif in the pore region, which constitutes the potassium selectivity filter in potassium channels. Nevertheless, HCN channels are nonselective cation channels conducting both sodium and potassium ions (selectivity for $\mathrm{K}^{+} / \mathrm{Na}^{+}$ $\sim 4: 1$ ). Under physiological conditions, activation of the channels leads to influx of sodium ions, resulting 
in depolarization. Third, cyclic nucleotides, particularly cAMP, stimulate the channels by accelerating their activation kinetics and by shifting the activation curve in the positive direction. However, cAMP is not required for channel opening. HCN channels contain a cyclic nucleotide-binding domain (CNBD) in the carboxyterminus. Truncation experiments have shown that the cyclic nucleotide-binding domain inhibits gating in the cAMP-unbound state, whereas cAMP binding relieves this inhibition [164].

The recent cryo-EM structure of HCN1 [165] together with the crystal structure of a cyclic nucleotide-binding domain [166] yielded important insights into the peculiar characteristic outlined above. As compared to potassium channels, the outer half of the selectivity filter in HCNs is enlarged and two of the potential four potassium binding sites are lacking. This results in a loss of the kinetic selectivity for potassium present in potassium channels, where four binding sites in the permeation pathway are present. Second, the closed pore is stabilized by the voltage sensor (S4 segment) and other domains in the depolarized state. It is proposed that the hyperpolarization-induced downward movement of S4 disrupts these interactions, leading to spontaneous pore opening. Third, binding of cAMP induces small conformational changes, leading to a rotation towards opening of the inner gate. However, HCN1 is barely modulated by cyclic nucleotides, so it remains to be seen if this structural mechanism also operates in HCN2 and HCN4, which are strongly modulated by cAMP.

The individual isoforms possess characteristic properties, which have been investigated in heterologous expression systems and were confirmed by using knockout mice of each isoform [167-171]. Beneath the different sensitivities toward cyclic nucleotides, the isoforms strongly differ in the rate of channel opening. HCN1 is the fastest activating isoform, $\mathrm{HCN} 2$ and $\mathrm{HCN} 3$ possess an intermediate activation kinetic, and $\mathrm{HCN} 4$ is the slowest $\mathrm{HCN}$ channel with an activation time constant up to several seconds.

In principle, activation of $\mathrm{HCN}$ channels leads to depolarisation and promotes AP generation. Since neuronal hyperexcitability and spontaneous AP generation of nociceptors contribute to the generation of pathological pain, HCN channels and, in particular, HCN2 may be involved in the sensitization of nociceptors in chronic pain conditions. In line with this assumption, an enhancement of the current flowing through these channels $\left(\mathrm{I}_{\mathrm{h}}\right)$ has been directly shown in different models of neuropathic [172-174] and inflammatory [175] pain. The increase in $\mathrm{I}_{\mathrm{h}}$ has been attributed to an upregulation of HCN transcript and/or protein [113,175-179], upregulation of the potential auxiliary subunit MiRP1 [174], increased intracellular cAMP levels [180], and PKA-dependent phosphorylation of HCN2 [181]. Nociceptor-specific deletion of HCN2 by using a Nav1.8-Cre transgene to delete the floxed HCN2 exons directly demonstrated the important role of this channel in pathological pain conditions $[179,182]$. In two different models of neuropathic pain, HCN2 emerged as a key regulator since its deletion strongly reduced [183] and even abolished [182] the increase in nociceptive sensitivity. Moreover, in diabetic mice, deletion or block of HCN2 prevented the mechanical allodynia following diabetic neuropathy [180]. In inflammatory pain, the importance of HCN2 was also shown, but the extent differed between the inflammatory compound (carrageenan, PGE2, 8-bromo-cAMP, zymosan A, and CFA) and behavioural test (mechanical and heat hypersensitivity) used $[179,182]$. It is proposed that HCN2 channels determine nociceptor hypersensitivity if the inflammatory signal transduction pathways result in an increase of cAMP, which may directly modulate channel activity via binding to the CNBD [184] or indirectly via activation of PKA and phosphorylation of HCN2 or associated proteins [183].

However, in spite of these promising findings in murine models, a recent human phase 2 study did not find any effect of ivabradine on capsaicin-induced hyperalgesia and pain in healthy volunteers [185]. Ivabradine caused a significant heart-rate reduction, indicating that the dose was sufficient to block HCN4 and HCN1 channels in the sinoatrial node. These results suggest that it might be necessary to develop HCN2-selective substances (which do not cross the blood-brain barrier [167]) to serve as analgesics. Beyond that, it is still possible that ivabradine is effective in other human pain models distinct from the neurogenic inflammation induced by TRPV1 activation. 


\section{Conclusion}

Unexpected properties of several ion channels with importance for the pain field were discussed (Table 1). We hope that the selective and non-comprehensive choices help to transfer knowledge within the field. Considering the possibility that such findings in other channels might explain otherwise not understood issues and facilitate scientific progress.

Table 1. Overview for the mentioned noncanonical ion channel features: canonical features not discussed in the review are considered ligand- and voltage-gating, selective permeability, interaction with other proteins, fractional presence at the plasma membrane, heteromerisation, modulation by intracellular cascades, and a change of expression.

\begin{tabular}{cc}
\hline Noncanonical Property & Ion Channel and References \\
\hline slow inactivation & Nav [9,12-33] \\
\hline resurgent current during membrane repolarisation & Nav (1.2, 1.5, 1.6, 1.7, 1.8) [29,34-41] \\
\hline side fenestrations of the channel pore & Nav [9,10,46-49] \\
\hline alternative ion permeation pathway across the membrane & Nav (1.2, 1.4, 1.5) [50-55] \\
TRPM3 [135-138]
\end{tabular}

Author Contributions: C.I.C., C.T., J.M., A.L. (Angelika Lampert), S.B.M., A.L. (Andreas Ludwig), and M.J.M.F. wrote the manuscript.

Funding: This research was supported by the Austrian Science Fund (FWF): P 32534.

Conflicts of Interest: The authors declare no conflict of interest.

\section{Abbreviations}

AKAP A-kinase anchor protein

HCN Hyperpolarization-activated cyclic nucleotide-gated channel

Kv voltage-gated potassium channel

KvS Silent potassium channel subunit

K2P Two Pore domain potassium channel

Kir $\quad$ Kir inwardly rectifying potassium channel

Nav Voltage-gated sodium channel

TRP Transient receptor potential channels

VAMP Vesicle-associated membrane protein 


\section{References}

1. Hille, B. Ion Channels of Excitable Membranes, 3rd ed.; Sinauer Associates: Sunderland, MA, USA, 2001.

2. Catterall, W.A. From Ionic Currents to Molecular Mechanisms: The Structure and Function of Voltage-Gated Sodium Channels. Neuron 2000, 26, 13-25. [CrossRef]

3. Catterall, W.A. International Union of Pharmacology. XLVII. Nomenclature and Structure-Function Relationships of Voltage-Gated Sodium Channels. Pharmacol. Rev. 2005, 57, 397-409. [CrossRef] [PubMed]

4. Lampert, A.; O’Reilly, A.O.; Reeh, P.; Leffler, A. Sodium channelopathies and pain. Pflugers Arch. 2010, 460, 249-263. [CrossRef] [PubMed]

5. Emery, E.C.; Luiz, A.P.; Wood, J.N. Nav1.7 and other voltage-gated sodium channels as drug targets for pain relief. Expert Opin Ther Targets 2016, 20, 975-983. [CrossRef] [PubMed]

6. Ahern, C.A.; Payandeh, J.; Bosmans, F.; Chanda, B. The hitchhiker's guide to the voltage-gated sodium channel galaxy. J. Gen. Physiol. 2016, 147, 1-24. [CrossRef] [PubMed]

7. Peters, C.H.; Ruben, P.C. Introduction to Sodium Channels. In Voltage Gated Sodium Channels; Ruben, P.C., Ed.; Handbook of Experimental Pharmacology; Springer: Berlin/Heidelberg, Germany, 2014; pp. 1-6.

8. Yan, Z.; Zhou, Q.; Wang, L.; Wu, J.; Zhao, Y.; Huang, G.; Peng, W.; Shen, H.; Lei, J.; Yan, N. Structure of the Nav1.4- $\beta 1$ Complex from Electric Eel. Cell 2017, 170, 470-482. [CrossRef] [PubMed]

9. Pan, X.; Li, Z.; Zhou, Q.; Shen, H.; Wu, K.; Huang, X.; Chen, J.; Zhang, J.; Zhu, X.; Lei, J.; et al. Structure of the human voltage-gated sodium channel Nav1.4 in complex with $\beta 1$. Science 2018, 362, eaau2486. [CrossRef]

10. Shen, H.; Liu, D.; Wu, K.; Lei, J.; Yan, N. Structures of human Nav1.7 channel in complex with auxiliary subunits and animal toxins. Science 2019, 363, 1303-1308. [CrossRef]

11. Clairfeuille, T.; Cloake, A.; Infield, D.T.; Llongueras, J.P.; Arthur, C.P.; Li, Z.R.; Jian, Y.; Martin-Eauclaire, M.-F.; Bougis, P.E.; Ciferri, C.; et al. Structural basis of $\alpha$-scorpion toxin action on Nav channels. Science 2019, 363, eaav8573. [CrossRef]

12. Barbosa, C.; Cummins, T.R. Unusual Voltage-Gated Sodium Currents as Targets for Pain. In Current Topics in Membranes; French, R.J., Noskov, S.Y., Eds.; Academic Press: Cambridge, MA, USA, 2016; Volume 78, pp. 599-638.

13. Ulbricht, W. Sodium Channel Inactivation: Molecular Determinants and Modulation. Physiol. Rev. 2005, 85, 1271-1301. [CrossRef]

14. Silva, J. Slow Inactivation of Na+ Channels. In Voltage Gated Sodium Channels; Ruben, P.C., Ed.; Handbook of Experimental Pharmacology; Springer: Berlin/Heidelberg, Germany, 2014; pp. 33-49.

15. Chatterjee, S.; Vyas, R.; Chalamalasetti, S.V.; Sahu, I.D.; Clatot, J.; Wan, X.; Lorigan, G.A.; Deschênes, I.; Chakrapani, S. The voltage-gated sodium channel pore exhibits conformational flexibility during slow inactivation. J. Gen. Physiol. 2018, 150, 1333-1347. [CrossRef] [PubMed]

16. Xiong, W.; Li, R.A.; Tian, Y.; Tomaselli, G.F. Molecular Motions of the Outer Ring of Charge of the Sodium Channel: Do They Couple to Slow Inactivation? J. Gen. Physiol. 2003, 122, 323-332. [CrossRef] [PubMed]

17. Cummins, T.R.; Dib-Hajj, S.D.; Waxman, S.G. Electrophysiological Properties of Mutant Nav1.7 Sodium Channels in a Painful Inherited Neuropathy. J. Neurosci. 2004, 24, 8232-8236. [CrossRef] [PubMed]

18. Dib-Hajj, S.D.; Rush, A.M.; Cummins, T.R.; Hisama, F.M.; Novella, S.; Tyrrell, L.; Marshall, L.; Waxman, S.G. Gain-of-function mutation in Nav1.7 in familial erythromelalgia induces bursting of sensory neurons. Brain 2005, 128, 1847-1854. [CrossRef] [PubMed]

19. Choi, J.-S.; Dib-Hajj, S.D.; Waxman, S.G. Inherited erythermalgia: Limb pain from an S4 charge-neutral Na channelopathy. Neurology 2006, 67, 1563-1567. [CrossRef] [PubMed]

20. Harty, T.P.; Dib-Hajj, S.D.; Tyrrell, L.; Blackman, R.; Hisama, F.M.; Rose, J.B.; Waxman, S.G. Nav1.7 Mutant A863P in Erythromelalgia: Effects of Altered Activation and Steady-State Inactivation on Excitability of Nociceptive Dorsal Root Ganglion Neurons. J. Neurosci. 2006, 26, 12566-12575. [CrossRef]

21. Lampert, A.; Dib-Hajj, S.D.; Tyrrell, L.; Waxman, S.G. Size Matters: Erythromelalgia Mutation S241T in Nav1.7 Alters Channel Gating. J. Biol. Chem. 2006, 281, 36029-36035. [CrossRef]

22. Sheets, P.L.; Jackson, J.O.; Waxman, S.G.; Dib-Hajj, S.D.; Cummins, T.R. A Nav1.7 channel mutation associated with hereditary erythromelalgia contributes to neuronal hyperexcitability and displays reduced lidocaine sensitivity. J. Physiol. 2007, 581, 1019-1031. [CrossRef] 
23. Cheng, X.; Dib-Hajj, S.D.; Tyrrell, L.; Waxman, S.G. Mutation I136V alters electrophysiological properties of the NaV1.7 channel in a family with onset of erythromelalgia in the second decade. Mol. Pain 2008, 4, 1. [CrossRef]

24. Han, C.; Dib-Hajj, S.D.; Lin, Z.; Li, Y.; Eastman, E.M.; Tyrrell, L.; Cao, X.; Yang, Y.; Waxman, S.G. Earlyand late-onset inherited erythromelalgia: Genotype-phenotype correlation. Brain 2009, 132, 1711-1722. [CrossRef]

25. Ahn, H.-S.; Dib-Hajj, S.D.; Cox, J.J.; Tyrrell, L.; Elmslie, F.V.; Clarke, A.A.; Drenth, J.P.H.; Woods, C.G.; Waxman, S.G. A new Nav1.7 sodium channel mutation I234T in a child with severe pain. Eur. J. Pain 2010, 14, 944-950. [CrossRef] [PubMed]

26. Estacion, M.; Choi, J.S.; Eastman, E.M.; Lin, Z.; Li, Y.; Tyrrell, L.; Yang, Y.; Dib-Hajj, S.D.; Waxman, S.G. Can robots patch-clamp as well as humans? Characterization of a novel sodium channel mutation. J. Physiol. 2010, 588, 1915-1927. [CrossRef] [PubMed]

27. Cheng, X.; Dib-Hajj, S.D.; Tyrrell, L.; te Morsche, R.H.; Drenth, J.P.H.; Waxman, S.G. Deletion mutation of sodium channel NaV1.7 in inherited erythromelalgia: Enhanced slow inactivation modulates dorsal root ganglion neuron hyperexcitability. Brain 2011, 134, 1972-1986. [CrossRef] [PubMed]

28. Estacion, M.; Yang, Y.; Dib-Hajj, S.D.; Tyrrell, L.; Lin, Z.; Yang, Y.; Waxman, S.G. A new Nav1.7 mutation in an erythromelalgia patient. Biochem. Biophys. Res. Commun. 2013, 432, 99-104. [CrossRef] [PubMed]

29. Hampl, M.; Eberhardt, E.; O'Reilly, A.O.; Lampert, A. Sodium channel slow inactivation interferes with open channel block. Sci. Rep. 2016, 6, 25974. [CrossRef]

30. Lampert, A.; Eberhardt, M.; Waxman, S.G. Altered Sodium Channel Gating as Molecular Basis for Pain: Contribution of Activation, Inactivation, and Resurgent Currents. In Voltage Gated Sodium Channels; Ruben, P.C., Ed.; Handbook of Experimental Pharmacology; Springer: Berlin/Heidelberg, Germany, 2014; pp. 91-110.

31. Zimmermann, K.; Leffler, A.; Babes, A.; Cendan, C.M.; Carr, R.W.; Kobayashi, J.; Nau, C.; Wood, J.N.; Reeh, P.W. Sensory neuron sodium channel $\mathrm{Na}_{\mathrm{v}} 1.8$ is essential for pain at low temperatures. Nature 2007, 447, 856-859. [CrossRef] [PubMed]

32. Villalba-Galea, C.A. Hysteresis in voltage-gated channels. Channels (Austin) 2016, 11, 140-155. [CrossRef]

33. Meents, J.E.; Bressan, E.; Sontag, S.; Foerster, A.; Hautvast, P.; Rösseler, C.; Hampl, M.; Schüler, H.; Goetzke, R.; Le, T.K.C.; et al. The role of Nav1.7 in human nociceptors: Insights from human induced pluripotent stem cell-derived sensory neurons of erythromelalgia patients. Pain. 2019, 160, 1327. [CrossRef]

34. Raman, I.M.; Bean, B.P. Resurgent Sodium Current and Action Potential Formation in Dissociated Cerebellar Purkinje Neurons. J. Neurosci. 1997, 17, 4517-4526. [CrossRef]

35. Lewis, A.H.; Raman, I.M. Resurgent current of voltage-gated Na+ channels. J. Physiol. 2014, 592, 4825-4838. [CrossRef]

36. Meents, J.E.; Lampert, A. Studying Sodium Channel Gating in Heterologous Expression Systems. In Advanced Patch-Clamp Analysis for Neuroscientists; Korngreen, A., Ed.; Neuromethods; Springer: New York, NY, USA, 2016; pp. 37-65.

37. Grieco, T.M.; Malhotra, J.D.; Chen, C.; Isom, L.L.; Raman, I.M. Open-channel block by the cytoplasmic tail of sodium channel beta4 as a mechanism for resurgent sodium current. Neuron 2005, 45, 233-244. [CrossRef]

38. Rush, A.M.; Dib-Hajj, S.D.; Waxman, S.G. Electrophysiological properties of two axonal sodium channels, Nav1.2 and Nav1.6, expressed in mouse spinal sensory neurones. J. Physiol. 2005, 564, 803-815. [CrossRef]

39. Cummins, T.R.; Dib-Hajj, S.D.; Herzog, R.I.; Waxman, S.G. Nav1.6 channels generate resurgent sodium currents in spinal sensory neurons. FEBS Lett. 2005, 579, 2166-2170. [CrossRef]

40. Tan, Z.-Y.; Piekarz, A.D.; Priest, B.T.; Knopp, K.L.; Krajewski, J.L.; McDermott, J.S.; Nisenbaum, E.S.; Cummins, T.R. Tetrodotoxin-Resistant Sodium Channels in Sensory Neurons Generate Slow Resurgent Currents That Are Enhanced by Inflammatory Mediators. J. Neurosci. 2014, 34, 7190-7197. [CrossRef]

41. Theile, J.W.; Jarecki, B.W.; Piekarz, A.D.; Cummins, T.R. Nav1.7 mutations associated with paroxysmal extreme pain disorder, but not erythromelalgia, enhance Nav $\beta 4$ peptide-mediated resurgent sodium currents. J. Physiol. 2011, 589, 597-608. [CrossRef]

42. Ragsdale, D.S.; McPhee, J.C.; Scheuer, T.; Catterall, W.A. Molecular determinants of state-dependent block of $\mathrm{Na}+$ channels by local anesthetics. Science 1994, 265, 1724-1728. [CrossRef] 
43. Yarov-Yarovoy, V.; Brown, J.; Sharp, E.M.; Clare, J.J.; Scheuer, T.; Catterall, W.A. Molecular Determinants of Voltage-dependent Gating and Binding of Pore-blocking Drugs in Transmembrane Segment IIIS6 of the Na+ Channel $\alpha$ Subunit. J. Biol. Chem. 2001, 276, 20-27. [CrossRef]

44. Ahern, C.A.; Eastwood, A.L.; Dougherty, D.A.; Horn, R. Electrostatic contributions of aromatic residues in the local anesthetic receptor of voltage-gated sodium channels. Circ. Res. 2008, 102, 86-94. [CrossRef]

45. Hille Bertil Local anesthetics: Hydrophilic and hydrophobic pathways for the drug-receptor reaction. | JGP. Available online: http://jgp.rupress.org/content/69/4/497.long (accessed on 3 July 2019).

46. O'Reilly, A.O.; Eberhardt, E.; Weidner, C.; Alzheimer, C.; Wallace, B.A.; Lampert, A. Bisphenol A Binds to the Local Anesthetic Receptor Site to Block the Human Cardiac Sodium Channel. PLoS ONE 2012, 7, e41667. [CrossRef]

47. Kaczmarski, J.A.; Corry, B. Investigating the size and dynamics of voltage-gated sodium channel fenestrations. Channels (Austin) 2014, 8, 264-277. [CrossRef]

48. Smith, N.E.; Corry, B. Mutant bacterial sodium channels as models for local anesthetic block of eukaryotic proteins. Channels (Austin) 2016, 10, 225-237. [CrossRef]

49. El-Din, T.M.G.; Lenaeus, M.J.; Zheng, N.; Catterall, W.A. Fenestrations control resting-state block of a voltage-gated sodium channel. PNAS 2018, 115, 13111-13116. [CrossRef]

50. Sokolov, S.; Scheuer, T.; Catterall, W.A. Ion Permeation through a Voltage- Sensitive Gating Pore in Brain Sodium Channels Having Voltage Sensor Mutations. Neuron 2005, 47, 183-189. [CrossRef]

51. Sokolov, S.; Scheuer, T.; Catterall, W.A. Gating pore current in an inherited ion channelopathy. Nature 2007, 446, 76-78. [CrossRef]

52. Sokolov, S.; Scheuer, T.; Catterall, W.A. Depolarization-activated gating pore current conducted by mutant sodium channels in potassium-sensitive normokalemic periodic paralysis. PNAS 2008, 105, 19980-19985. [CrossRef]

53. Gosselin-Badaroudine, P.; Delemotte, L.; Moreau, A.; Klein, M.L.; Chahine, M. Gating pore currents and the resting state of Nav1.4 voltage sensor domains. PNAS 2012, 109, 19250-19255. [CrossRef]

54. Moreau, A.; Gosselin-Badaroudine, P.; Mercier, A.; Burger, B.; Keller, D.I.; Chahine, M. A leaky voltage sensor domain of cardiac sodium channels causes arrhythmias associated with dilated cardiomyopathy. Sci. Rep. 2018, 8, 13804. [CrossRef]

55. Moreau, A.; Gosselin-Badaroudine, P.; Chahine, M. Gating pore currents, a new pathological mechanism underlying cardiac arrhythmias associated with dilated cardiomyopathy. Channels (Austin) 2015, 9, 139-144. [CrossRef]

56. Tsantoulas, C.; McMahon, S.B. Opening paths to novel analgesics: The role of potassium channels in chronic pain. Trends Neurosci. 2014, 37, 146-158. [CrossRef]

57. Tsantoulas, C. Emerging potassium channel targets for the treatment of pain. Curr. Opin. Support. Palliat. Care 2015, 9, 147-154. [CrossRef]

58. Pillozzi, S.; Brizzi, M.F.; Bernabei, P.A.; Bartolozzi, B.; Caporale, R.; Basile, V.; Boddi, V.; Pegoraro, L.; Becchetti, A.; Arcangeli, A. VEGFR-1 (FLT-1), $\beta 1$ integrin, and hERG K+ channel for a macromolecular signaling complex in acute myeloid leukemia: Role in cell migration and clinical outcome. Blood 2007, 110, 1238-1250. [CrossRef]

59. Feinshreiber, L.; Singer-Lahat, D.; Ashery, U.; Lotan, I. Voltage-gated Potassium Channel as a Facilitator of Exocytosis. Ann. N. Y. Acad. Sci. 2009, 1152, 87-92. [CrossRef]

60. Jang, S.H.; Choi, C.; Hong, S.-G.; Yarishkin, O.V.; Bae, Y.M.; Kim, J.G.; O'Grady, S.M.; Yoon, K.-A.; Kang, K.-S.; $\mathrm{Ryu}$, P.D.; et al. Silencing of Kv4.1 potassium channels inhibits cell proliferation of tumorigenic human mammary epithelial cells. Biochem. Biophys. Res. Commun. 2009, 384, 180-186. [CrossRef]

61. MacKinnon, R. Potassium channels. FEBS Lett. 2003, 555, 62-65. [CrossRef]

62. Fernández-Mariño, A.I.; Harpole, T.J.; Oelstrom, K.; Delemotte, L.; Chanda, B. Gating interaction maps reveal a noncanonical electromechanical coupling mode in the Shaker K+ channel. Nat. Struct. Mol. Biol. 2018, 25, 320-326. [CrossRef]

63. Lörinczi, É.; Gómez-Posada, J.C.; de la Peña, P.; Tomczak, A.P.; Fernández-Trillo, J.; Leipscher, U.; Stühmer, W.; Barros, F.; Pardo, L.A. Voltage-dependent gating of $\mathrm{KCNH}$ potassium channels lacking a covalent link between voltage-sensing and pore domains. Nat. Commun. 2015, 6, 6672. [CrossRef]

64. Wang, W.; MacKinnon, R. Cryo-EM Structure of the Open Human Ether-à-go-go -Related K + Channel hERG. Cell 2017, 169, 422-430. [CrossRef] 
65. Hao, J.; Padilla, F.; Dandonneau, M.; Lavebratt, C.; Lesage, F.; Noël, J.; Delmas, P. Kv1.1 Channels Act as Mechanical Brake in the Senses of Touch and Pain. Neuron 2013, 77, 899-914. [CrossRef]

66. Hao, J.; Delmas, P. Multiple Desensitization Mechanisms of Mechanotransducer Channels Shape Firing of Mechanosensory Neurons. J. Neurosci. 2010, 30, 13384-13395. [CrossRef]

67. Liang, L.; Gu, X.; Zhao, J.-Y.; Wu, S.; Miao, X.; Xiao, J.; Mo, K.; Zhang, J.; Lutz, B.M.; Bekker, A.; et al. G9a participates in nerve injury-induced Kcna2 downregulation in primary sensory neurons. Sci. Rep. 2016, 6, 37704. [CrossRef]

68. Zhao, X.; Tang, Z.; Zhang, H.; Atianjoh, F.E.; Zhao, J.-Y.; Liang, L.; Wang, W.; Guan, X.; Kao, S.-C.; Tiwari, V.; et al. A long noncoding RNA contributes to neuropathic pain by silencing Kcna2 in primary afferent neurons. Nat. Neurosci. 2013, 16, 1024-1031. [CrossRef]

69. Laumet, G.; Garriga, J.; Chen, S.-R.; Zhang, Y.; Li, D.-P.; Smith, T.M.; Dong, Y.; Jelinek, J.; Cesaroni, M.; Issa, J.-P.; et al. G9a is essential for epigenetic silencing of $\mathrm{K}+$ channel genes in acute-to-chronic pain transition. Nat. Neurosci. 2015, 18, 1746-1755. [CrossRef]

70. Briggs, J.A.; Wolvetang, E.J.; Mattick, J.S.; Rinn, J.L.; Barry, G. Mechanisms of Long Non-coding RNAs in Mammalian Nervous System Development, Plasticity, Disease, and Evolution. Neuron 2015, 88, 861-877. [CrossRef]

71. Barry, G.; Briggs, J.A.; Hwang, D.W.; Nayler, S.P.; Fortuna, P.R.J.; Jonkhout, N.; Dachet, F.; Maag, J.L.V.; Mestdagh, P.; Singh, E.M.; et al. The long non-coding RNA NEAT1 is responsive to neuronal activity and is associated with hyperexcitability states. Sci. Rep. 2017, 7, 40127. [CrossRef]

72. Speca, D.J.; Ogata, G.; Mandikian, D.; Bishop, H.I.; Wiler, S.W.; Eum, K.; Wenzel, H.J.; Doisy, E.T.; Matt, L.; Campi, K.L.; et al. Deletion of the Kv2.1 delayed rectifier potassium channel leads to neuronal and behavioral hyperexcitability: Kv2.1 deletion and hyperexcitability. Genes Brain Behav. 2014, 13, 394-408. [CrossRef]

73. Torkamani, A.; Bersell, K.; Jorge, B.S.; Bjork, R.L.; Friedman, J.R.; Bloss, C.S.; Cohen, J.; Gupta, S.; Naidu, S.; Vanoye, C.G.; et al. De novo KCNB1 mutations in epileptic encephalopathy: KCNB1 Mutations. Ann. Neurol. 2014, 76, 529-540. [CrossRef]

74. Tsantoulas, C.; Zhu, L.; Yip, P.; Grist, J.; Michael, G.J.; McMahon, S.B. Kv2 dysfunction after peripheral axotomy enhances sensory neuron responsiveness to sustained input. Exp. Neurol. 2014, 251, 115-126. [CrossRef]

75. Thiffault, I.; Speca, D.J.; Austin, D.C.; Cobb, M.M.; Eum, K.S.; Safina, N.P.; Grote, L.; Farrow, E.G.; Miller, N.; Soden, S.; et al. A novel epileptic encephalopathy mutation in KCNB1 disrupts Kv2.1 ion selectivity, expression, and localization. J. Gen. Physiol. 2015, 146, 399-410. [CrossRef]

76. Bocksteins, E.; Snyders, D.J. Electrically Silent Kv Subunits: Their Molecular and Functional Characteristics. Physiology 2012, 27, 73-84. [CrossRef]

77. Kramer, J.W.; Post, M.A.; Brown, A.M.; Kirsch, G.E. Modulation of potassium channel gating by coexpression of Kv2.1 with regulatory Kv5.1 or Kv6.1 $\alpha$-subunits. Am. J. Physiol. Cell Physiol. 1998, 274, C1501-C1510. [CrossRef]

78. Salinas, M.; Duprat, F.; Heurteaux, C.; Hugnot, J.P.; Lazdunski, M. New modulatory alpha subunits for mammalian Shab K+ channels. J. Biol. Chem. 1997, 272, 24371-24379. [CrossRef]

79. Wu, H.; Cowing, J.A.; Michaelides, M.; Wilkie, S.E.; Jeffery, G.; Jenkins, S.A.; Mester, V.; Bird, A.C.; Robson, A.G.; Holder, G.E.; et al. Mutations in the gene KCNV2 encoding a voltage-gated potassium channel subunit cause "cone dystrophy with supernormal rod electroretinogram" in humans. Am. J. Hum. Genet. 2006, 79, 574-579. [CrossRef]

80. Czirják, G.; Tóth, Z.E.; Enyedi, P. Characterization of the Heteromeric Potassium Channel Formed by Kv2.1 and the Retinal Subunit Kv8.2 in Xenopus Oocytes. J. Neurophysiol. 2007, 98, 1213-1222. [CrossRef]

81. Stockman, A.; Henning, G.B.; Michaelides, M.; Moore, A.T.; Webster, A.R.; Cammack, J.; Ripamonti, C. Cone Dystrophy With "Supernormal" Rod ERG: Psychophysical Testing Shows Comparable Rod and Cone Temporal Sensitivity Losses With No Gain in Rod Function. Invest. Ophthalmol. Vis. Sci. 2014, 55, 832-840. [CrossRef]

82. Sano, A.; Mikami, M.; Nakamura, M.; Ueno, S.-I.; Tanabe, H.; Kaneko, S. Positional candidate approach for the gene responsible for benign adult familial myoclonic epilepsy. Epilepsia 2002, 43, 26-31. [CrossRef]

83. Bergren, S.K.; Rutter, E.D.; Kearney, J.A. Fine Mapping of an Epilepsy Modifier Gene on Mouse Chromosome 19. Mamm. Genome 2009, 20, 359-366. [CrossRef] 
84. Jorge, B.S.; Campbell, C.M.; Miller, A.R.; Rutter, E.D.; Gurnett, C.A.; Vanoye, C.G.; George, A.L.; Kearney, J.A. Voltage-gated potassium channel KCNV2 (Kv8.2) contributes to epilepsy susceptibility. Proc. Natl. Acad. Sci. USA 2011, 108, 5443-5448. [CrossRef]

85. Tsantoulas, C.; Zhu, L.; Shaifta, Y.; Grist, J.; Ward, J.P.T.; Raouf, R.; Michael, G.J.; McMahon, S.B. Sensory Neuron Downregulation of the Kv9.1 Potassium Channel Subunit Mediates Neuropathic Pain following Nerve Injury. J. Neurosci. 2012, 32, 17502-17513. [CrossRef]

86. Tsantoulas, C.; Denk, F.; Signore, M.; Nassar, M.A.; Futai, K.; McMahon, S.B. Mice lacking KCNS1 in peripheral neurons show increased basal and neuropathic pain sensitivity. Pain 2018, 159, 1641-1651. [CrossRef]

87. Patel, A.J.; Lazdunski, M.; Honoré, E. Kv2.1/Kv9.3, a novel ATP-dependent delayed-rectifier K+ channel in oxygen-sensitive pulmonary artery myocytes. EMBO J. 1997, 16, 6615-6625. [CrossRef]

88. Richardson, F.C.; Kaczmarek, L.K. Modification of delayed rectifier potassium currents by the Kv9.1 potassium channel subunit. Hear. Res. 2000, 147, 21-30. [CrossRef]

89. Costigan, M.; Belfer, I.; Griffin, R.S.; Dai, F.; Barrett, L.B.; Coppola, G.; Wu, T.; Kiselycznyk, C.; Poddar, M.; $\mathrm{Lu}, \mathrm{Y}$; , et al. Multiple chronic pain states are associated with a common amino acid-changing allele in KCNS1. Brain 2010, 133, 2519-2527. [CrossRef]

90. Lafrenière, R.G.; Rouleau, G.A. Identification of novel genes involved in migraine. Headache 2012, 52, 107-110. [CrossRef]

91. Lee, M.C.; Nahorski, M.S.; Hockley, J.R.F.; Lu, V.B.; Stouffer, K.; Fletcher, E.; Ison, G.; Brown, C.; Wheeler, D.; Ernfors, P.; et al. Human labor pain is influenced by the voltage-gated potassium channel KV6.4 subunit. Biorxiv 2018. [CrossRef]

92. Sarmiere, P.D.; Weigle, C.M.; Tamkun, M.M. The Kv2.1 K+ channel targets to the axon initial segment of hippocampal and cortical neurons in culture and in situ. BMC Neurosci. 2008, 9, 112. [CrossRef]

93. O'Connell, K.M.S.; Loftus, R.; Tamkun, M.M. Localization-dependent activity of the Kv2.1 delayed-rectifier K+ channel. Proc. Natl. Acad. Sci. USA 2010, 107, 12351-12356. [CrossRef]

94. Fox, P.D.; Loftus, R.J.; Tamkun, M.M. Regulation of Kv2.1 K(+) conductance by cell surface channel density. J. Neurosci. 2013, 33, 1259-1270. [CrossRef]

95. Misonou, H.; Trimmer, J.S. Determinants of voltage-gated potassium channel surface expression and localization in Mammalian neurons. Crit. Rev. Biochem. Mol. Biol. 2004, 39, 125-145. [CrossRef]

96. Romer, S.H.; Deardorff, A.S.; Fyffe, R.E.W. Activity-dependent redistribution of Kv2.1 ion channels on rat spinal motoneurons. Physiol. Rep. 2016, 4, e13039. [CrossRef]

97. Antonucci, D.E.; Lim, S.T.; Vassanelli, S.; Trimmer, J.S. Dynamic localization and clustering of dendritic Kv2.1 voltage-dependent potassium channels in developing hippocampal neurons. Neuroscience 2001, 108, 69-81. [CrossRef]

98. King, A.N.; Manning, C.F.; Trimmer, J.S. A unique ion channel clustering domain on the axon initial segment of mammalian neurons. J. Comp. Neurol. 2014, 522, 2594-2608. [CrossRef] [PubMed]

99. Fox, P.D.; Haberkorn, C.J.; Akin, E.J.; Seel, P.J.; Krapf, D.; Tamkun, M.M. Induction of stable ER-plasma-membrane junctions by Kv2.1 potassium channels. J. Cell Sci. 2015, 128, 2096-2105. [CrossRef] [PubMed]

100. Johnson, B.; Leek, A.N.; Solé, L.; Maverick, E.E.; Levine, T.P.; Tamkun, M.M. Kv2 potassium channels form endoplasmic reticulum/plasma membrane junctions via interaction with VAPA and VAPB. PNAS 2018, 115, E7331-E7340. [CrossRef] [PubMed]

101. Kirmiz, M.; Vierra, N.C.; Palacio, S.; Trimmer, J.S. Identification of VAPA and VAPB as Kv2 Channel-Interacting Proteins Defining Endoplasmic Reticulum-Plasma Membrane Junctions in Mammalian Brain Neurons. J. Neurosci. 2018, 38, 7562-7584. [CrossRef] [PubMed]

102. De Kovel, C.G.F.; Syrbe, S.; Brilstra, E.H.; Verbeek, N.; Kerr, B.; Dubbs, H.; Bayat, A.; Desai, S.; Naidu, S.; Srivastava, S.; et al. Neurodevelopmental Disorders Caused by De Novo Variants in KCNB1 Genotypes and Phenotypes. JAMA Neurol. 2017, 74, 1228-1236. [CrossRef] [PubMed]

103. MacKenzie, G.; Franks, N.P.; Brickley, S.G. Two-pore domain potassium channels enable action potential generation in the absence of voltage-gated potassium channels. Pflugers Arch. 2015, 467, 989-999. [CrossRef]

104. Bockenhauer, D.; Zilberberg, N.; Goldstein, S.a.N. KCNK2: Reversible conversion of a hippocampal potassium leak into a voltage-dependent channel. Nat. Neurosci. 2001, 4, 486. [CrossRef] 
105. Brickley, S.G.; Revilla, V.; Cull-Candy, S.G.; Wisden, W.; Farrant, M. Adaptive regulation of neuronal excitability by a voltage- independent potassium conductance. Nature 2001, 409, 88. [CrossRef]

106. Schewe, M.; Nematian-Ardestani, E.; Sun, H.; Musinszki, M.; Cordeiro, S.; Bucci, G.; de Groot, B.L.; Tucker, S.J.; Rapedius, M.; Baukrowitz, T. A Non-canonical Voltage-Sensing Mechanism Controls Gating in K2P K(+) Channels. Cell 2016, 164, 937-949. [CrossRef]

107. Chemin, J.; Patel, A.J.; Duprat, F.; Lauritzen, I.; Lazdunski, M.; Honoré, E. A phospholipid sensor controls mechanogating of the K+ channel TREK-1. EMBO J. 2005, 24, 44-53. [CrossRef]

108. Alloui, A.; Zimmermann, K.; Mamet, J.; Duprat, F.; Noël, J.; Chemin, J.; Guy, N.; Blondeau, N.; Voilley, N.; Rubat-Coudert, C.; et al. TREK-1, a K+ channel involved in polymodal pain perception. EMBO J. 2006, 25, 2368-2376. [CrossRef] [PubMed]

109. Noël, J.; Zimmermann, K.; Busserolles, J.; Deval, E.; Alloui, A.; Diochot, S.; Guy, N.; Borsotto, M.; Reeh, P.; Eschalier, A.; et al. The mechano-activated $\mathrm{K}+$ channels TRAAK and TREK-1 control both warm and cold perception. EMBO J. 2009, 28, 1308-1318. [CrossRef] [PubMed]

110. Brohawn, S.G.; Su, Z.; MacKinnon, R. Mechanosensitivity is mediated directly by the lipid membrane in TRAAK and TREK1 K+ channels. PNAS 2014, 111, 3614-3619. [CrossRef] [PubMed]

111. Brohawn, S.G.; Campbell, E.B.; MacKinnon, R. Physical mechanism for gating and mechanosensitivity of the human TRAAK K+ channel. Nature 2014, 516, 126-130. [CrossRef] [PubMed]

112. Pereira, V.; Busserolles, J.; Christin, M.; Devilliers, M.; Poupon, L.; Legha, W.; Alloui, A.; Aissouni, Y.; Bourinet, E.; Lesage, F.; et al. Role of the TREK2 potassium channel in cold and warm thermosensation and in pain perception. Pain 2014, 155, 2534-2544. [CrossRef] [PubMed]

113. Descoeur, J.; Pereira, V.; Pizzoccaro, A.; Francois, A.; Ling, B.; Maffre, V.; Couette, B.; Busserolles, J.; Courteix, C.; Noel, J.; et al. Oxaliplatin-induced cold hypersensitivity is due to remodelling of ion channel expression in nociceptors. EMBO Mol. Med. 2011, 3, 266-278. [CrossRef] [PubMed]

114. Franchini, L.; Levi, G.; Visentin, S. Inwardly rectifying K+ channels influence Ca2+ entry due to nucleotide receptor activation in microglia. Cell Calcium 2004, 35, 449-459. [CrossRef] [PubMed]

115. Janigro, D.; Gasparini, S.; D’Ambrosio, R.; Ii, G.M.; DiFrancesco, D. Reduction of K+ Uptake in Glia Prevents Long-Term Depression Maintenance and Causes Epileptiform Activity. J. Neurosci. 1997, 17, 2813-2824. [CrossRef] [PubMed]

116. D'Ambrosio, R.; Gordon, D.S.; Winn, H.R. Differential role of KIR channel and $\mathrm{Na}(+) / \mathrm{K}(+)$-pump in the regulation of extracellular $\mathrm{K}(+)$ in rat hippocampus. J. Neurophysiol. 2002, 87, 87-102. [CrossRef]

117. Vit, J.-P.; Ohara, P.T.; Bhargava, A.; Kelley, K.; Jasmin, L. Silencing the Kir4.1 potassium channel subunit in satellite glial cells of the rat trigeminal ganglion results in pain-like behavior in the absence of nerve injury. J. Neurosci. 2008, 28, 4161-4171. [CrossRef]

118. Takeda, M.; Tsuboi, Y.; Kitagawa, J.; Nakagawa, K.; Iwata, K.; Matsumoto, S. Potassium channels as a potential therapeutic target for trigeminal neuropathic and inflammatory pain. Mol. Pain 2011, 7, 5. [CrossRef] [PubMed]

119. Djukic, B.; Casper, K.B.; Philpot, B.D.; Chin, L.-S.; McCarthy, K.D. Conditional knock-out of Kir4.1 leads to glial membrane depolarization, inhibition of potassium and glutamate uptake, and enhanced short-term synaptic potentiation. J. Neurosci. 2007, 27, 11354-11365. [CrossRef] [PubMed]

120. Tang, X.; Hang, D.; Sand, A.; Kofuji, P. Variable loss of Kir4.1 channel function in SeSAME syndrome mutations. Biochem. Biophys. Res. Commun. 2010, 399, 537-541. [CrossRef] [PubMed]

121. Nishizawa, D.; Nagashima, M.; Katoh, R.; Satoh, Y.; Tagami, M.; Kasai, S.; Ogai, Y.; Han, W.; Hasegawa, J.; Shimoyama, N.; et al. Association between KCNJ6 (GIRK2) gene polymorphisms and postoperative analgesic requirements after major abdominal surgery. PLoS ONE 2009, 4, e7060. [CrossRef] [PubMed]

122. Nishizawa, D.; Fukuda, K.; Kasai, S.; Ogai, Y.; Hasegawa, J.; Sato, N.; Yamada, H.; Tanioka, F.; Sugimura, H.; Hayashida, M.; et al. Association between KCNJ6 (GIRK2) gene polymorphism rs2835859 and post-operative analgesia, pain sensitivity, and nicotine dependence. J. Pharmacol. Sci. 2014, 126, 253-263. [CrossRef] [PubMed]

123. Bruehl, S.; Denton, J.S.; Lonergan, D.; Koran, M.E.; Chont, M.; Sobey, C.; Fernando, S.; Bush, W.S.; Mishra, P.; Thornton-Wells, T.A. Associations between KCNJ6 (GIRK2) gene polymorphisms and pain-related phenotypes. Pain 2013, 154, 2853-2859. [CrossRef] [PubMed] 
124. Nockemann, D.; Rouault, M.; Labuz, D.; Hublitz, P.; McKnelly, K.; Reis, F.C.; Stein, C.; Heppenstall, P.A. The $\mathrm{K}(+)$ channel GIRK2 is both necessary and sufficient for peripheral opioid-mediated analgesia. EMBO Mol. Med. 2013, 5, 1263-1277. [CrossRef] [PubMed]

125. Lolicato, M.; Arrigoni, C.; Mori, T.; Sekioka, Y.; Bryant, C.; Clark, K.A.; Minor, D.L. K2P2.1 (TREK-1)-activator complexes reveal a cryptic selectivity filter binding site. Nature 2017, 547, 364-368. [CrossRef] [PubMed]

126. Al-Karagholi, M.A.-M.; Hansen, J.M.; Severinsen, J.; Jansen-Olesen, I.; Ashina, M. The KATP channel in migraine pathophysiology: A novel therapeutic target for migraine. J. Headache Pain 2017, 18. [CrossRef]

127. Nilius, B.; Prenen, J.; Owsianik, G. Irritating channels: The case of TRPA1. J. Physiol. (Lond.) 2011, 589, 1543-1549. [CrossRef]

128. Walker, R.G.; Willingham, A.T.; Zuker, C.S. A Drosophila mechanosensory transduction channel. Science 2000, 287, 2229-2234. [CrossRef] [PubMed]

129. Dai, Y. TRPs and pain. Semin. Immunopathol. 2016, 38, 277-291. [CrossRef] [PubMed]

130. Julius, D. TRP Channels and Pain. Annu. Rev. Cell Dev. Biol. 2013, 29, 355-384. [CrossRef] [PubMed]

131. González-Ramírez, R.; Chen, Y.; Liedtke, W.B.; Morales-Lázaro, S.L. TRP Channels and Pain. In Neurobiology of TRP Channels; Emir, T.L.R., Ed.; Frontiers in Neuroscience; CRC Press/Taylor \& Francis: Boca Raton, FL, USA, 2017.

132. Nilius, B.; Talavera, K.; Owsianik, G.; Prenen, J.; Droogmans, G.; Voets, T. Gating of TRP channels: A voltage connection?: Voltage dependence of TRP channels. J. Physiol. 2005, 567, 35-44. [CrossRef] [PubMed]

133. Bouron, A.; Kiselyov, K.; Oberwinkler, J. Permeation, regulation and control of expression of TRP channels by trace metal ions. Pflügers Arch. 2015, 467, 1143-1164. [CrossRef] [PubMed]

134. Lev, S.; Minke, B. Constitutive Activity of TRP Channels. In Methods in Enzymology; Elsevier: Amsterdam, Netherlands, 2010; Volume 484, pp. 591-612.

135. Vriens, J.; Held, K.; Janssens, A.; Tóth, B.I.; Kerselaers, S.; Nilius, B.; Vennekens, R.; Voets, T. Opening of an alternative ion permeation pathway in a nociceptor TRP channel. Nat. Chem. Biol. 2014, 10, 188-195. [CrossRef]

136. Held, K.; Gruss, F.; Aloi, V.D.; Janssens, A.; Ulens, C.; Voets, T.; Vriens, J. Mutations in the voltage-sensing domain affect the alternative ion permeation pathway in the TRPM3 channel. J. Physiol. (Lond.) 2018, 596, 2413-2432. [CrossRef]

137. Starace, D.M.; Bezanilla, F. Histidine scanning mutagenesis of basic residues of the S4 segment of the shaker k+ channel. J. Gen. Physiol. 2001, 117, 469-490. [CrossRef]

138. Tombola, F.; Ulbrich, M.H.; Isacoff, E.Y. The Voltage-Gated Proton Channel Hv1 Has Two Pores, Each Controlled by One Voltage Sensor. Neuron 2008, 58, 546-556. [CrossRef]

139. Xu, X.-Z.S.; Li, H.-S.; Guggino, W.B.; Montell, C. Coassembly of TRP and TRPL Produces a Distinct Store-Operated Conductance. Cell 1997, 89, 1155-1164. [CrossRef]

140. Owsianik, G.; Talavera, K.; Voets, T.; Nilius, B. Permeation and Selectivity of Trp Channels. Annu. Rev. Physiol. 2006, 68, 685-717. [CrossRef] [PubMed]

141. Nadler, M.J.S.; Hermosura, M.C.; Inabe, K.; Perraud, A.-L.; Zhu, Q.; Stokes, A.J.; Kurosaki, T.; Kinet, J.-P.; Penner, R.; Scharenberg, A.M.; et al. LTRPC7 is a Mg.ATP-regulated divalent cation channel required for cell viability. Nature 2001, 411, 590-595. [CrossRef] [PubMed]

142. Parnas, M.; Katz, B.; Minke, B. Open channel block by Ca2+ underlies the voltage dependence of drosophila TRPL channel. J. Gen. Physiol. 2007, 129, 17-28. [CrossRef] [PubMed]

143. Grimm, C.; Cuajungco, M.P.; van Aken, A.F.J.; Schnee, M.; Jörs, S.; Kros, C.J.; Ricci, A.J.; Heller, S. A helix-breaking mutation in TRPML3 leads to constitutive activity underlying deafness in the varitint-waddler mouse. Proc. Natl. Acad. Sci. USA 2007, 104, 19583-19588. [CrossRef] [PubMed]

144. Hinman, A.; Chuang, H.; Bautista, D.M.; Julius, D. TRP channel activation by reversible covalent modification. Proc. Natl. Acad. Sci. USA 2006, 103, 19564-19568. [CrossRef] [PubMed]

145. Macpherson, L.J.; Dubin, A.E.; Evans, M.J.; Marr, F.; Schultz, P.G.; Cravatt, B.F.; Patapoutian, A. Noxious compounds activate TRPA1 ion channels through covalent modification of cysteines. Nature 2007, 445, 541-545. [CrossRef] [PubMed]

146. Takahashi, N.; Kuwaki, T.; Kiyonaka, S.; Numata, T.; Kozai, D.; Mizuno, Y.; Yamamoto, S.; Naito, S.; Knevels, E.; Carmeliet, P.; et al. TRPA1 underlies a sensing mechanism for $\mathrm{O}_{2}$. Nat. Chem. Biol. 2011, 7, 701-711. [CrossRef] 
147. Bahia, P.K.; Parks, T.A.; Stanford, K.R.; Mitchell, D.A.; Varma, S.; Stevens, S.M.; Taylor-Clark, T.E. The exceptionally high reactivity of Cys 621 is critical for electrophilic activation of the sensory nerve ion channel TRPA1. J. Gen. Physiol. 2016, 147, 451-465. [CrossRef]

148. Chung, M.-K.; Güler, A.D.; Caterina, M.J. TRPV1 shows dynamic ionic selectivity during agonist stimulation. Nat. Neurosci. 2008, 11, 555-564. [CrossRef]

149. Chen, J.; Kim, D.; Bianchi, B.R.; Cavanaugh, E.J.; Faltynek, C.R.; Kym, P.R.; Reilly, R.M. Pore dilation occurs in TRPA1 but not in TRPM8 channels. Mol. Pain 2009, 5, 3. [CrossRef]

150. Banke, T.G. The dilated TRPA1 channel pore state is blocked by amiloride and analogues. Brain Res. 2011, 1381, 21-30. [CrossRef] [PubMed]

151. Li, M.; Toombes, G.E.S.; Silberberg, S.D.; Swartz, K.J. Physical basis of apparent pore dilation of ATP-activated P2X receptor channels. Nat. Neurosci. 2015, 18, 1577-1583. [CrossRef] [PubMed]

152. Bean, B.P. Pore dilation reconsidered. Nat. Neurosci. 2015, 18, 1534-1535. [CrossRef] [PubMed]

153. Raisinghani, M.; Zhong, L.; Jeffry, J.A.; Bishnoi, M.; Pabbidi, R.M.; Pimentel, F.; Cao, D.-S.; Steven Evans, M.; Premkumar, L.S. Activation characteristics of transient receptor potential ankyrin 1 and its role in nociception. Am. J. Physiol. Cell Physiol. 2011, 301, C587-C600. [CrossRef] [PubMed]

154. Meents, J.E.; Fischer, M.J.M.; McNaughton, P.A. Agonist-induced sensitisation of the irritant receptor ion channel TRPA1. J. Physiol. (Lond.) 2016, 594, 6643-6660. [CrossRef] [PubMed]

155. Birdsong, W.T.; Arttamangkul, S.; Clark, M.J.; Cheng, K.; Rice, K.C.; Traynor, J.R.; Williams, J.T. Increased agonist affinity at the $\mu$-opioid receptor induced by prolonged agonist exposure. J. Neurosci. 2013, 33, 4118-4127. [CrossRef] [PubMed]

156. Gauss, R.; Seifert, R.; Kaupp, U.B. Molecular identification of a hyperpolarization-activated channel in sea urchin sperm. Nature 1998, 393, 583. [CrossRef]

157. Ludwig, A.; Zong, X.; Jeglitsch, M.; Hofmann, F.; Biel, M. A family of hyperpolarization-activated mammalian cation channels. Nature 1998, 393, 587. [CrossRef]

158. Santoro, B.; Liu, D.T.; Yao, H.; Bartsch, D.; Kandel, E.R.; Siegelbaum, S.A.; Tibbs, G.R. Identification of a Gene Encoding a Hyperpolarization-Activated Pacemaker Channel of Brain. Cell 1998, 93, 717-729. [CrossRef]

159. Ludwig, A.; Zong, X.; Stieber, J.; Hullin, R.; Hofmann, F.; Biel, M. Two pacemaker channels from human heart with profoundly different activation kinetics. EMBO J. 1999, 18, 2323-2329. [CrossRef]

160. Seifert, R.; Scholten, A.; Gauss, R.; Mincheva, A.; Lichter, P.; Kaupp, U.B. Molecular characterization of a slowly gating human hyperpolarization-activated channel predominantly expressed in thalamus, heart, and testis. Proc. Natl. Acad. Sci. USA 1999, 96, 9391-9396. [CrossRef] [PubMed]

161. Robinson, R.B.; Siegelbaum, S.A. Hyperpolarization-Activated Cation Currents: From Molecules to Physiological Function. Annu. Rev. Physiol. 2003, 65, 453-480. [CrossRef] [PubMed]

162. Craven, K.B.; Zagotta, W.N. CNG and HCN channels: Two peas, one pod. Annu. Rev. Physiol. 2006, 68, 375-401. [CrossRef] [PubMed]

163. Biel, M.; Wahl-Schott, C.; Michalakis, S.; Zong, X. Hyperpolarization-activated cation channels: From genes to function. Physiol. Rev. 2009, 89, 847-885. [CrossRef] [PubMed]

164. Wainger, B.J.; DeGennaro, M.; Santoro, B.; Siegelbaum, S.A.; Tibbs, G.R. Molecular mechanism of cAMP modulation of HCN pacemaker channels. Nature 2001, 411, 805. [CrossRef]

165. Lee, C.-H.; MacKinnon, R. Structures of the Human HCN1 Hyperpolarization-Activated Channel. Cell 2017, 168, 111-120.e11. [CrossRef]

166. Zagotta, W.N.; Olivier, N.B.; Black, K.D.; Young, E.C.; Olson, R.; Gouaux, E. Structural basis for modulation and agonist specificity of HCN pacemaker channels. Nature 2003, 425, 200. [CrossRef]

167. Ludwig, A.; Budde, T.; Stieber, J.; Moosmang, S.; Wahl, C.; Holthoff, K.; Langebartels, A.; Wotjak, C.; Munsch, T.; Zong, X.; et al. Absence epilepsy and sinus dysrhythmia in mice lacking the pacemaker channel HCN2. EMBO J. 2003, 22, 216-224. [CrossRef]

168. Nolan, M.F.; Malleret, G.; Lee, K.H.; Gibbs, E.; Dudman, J.T.; Santoro, B.; Yin, D.; Thompson, R.F.; Siegelbaum, S.A.; Kandel, E.R.; et al. The hyperpolarization-activated HCN1 channel is important for motor learning and neuronal integration by cerebellar Purkinje cells. Cell 2003, 115, 551-564. [CrossRef]

169. Herrmann, S.; Stieber, J.; Stöckl, G.; Hofmann, F.; Ludwig, A. HCN4 provides a "depolarization reserve" and is not required for heart rate acceleration in mice. EMBO J. 2007, 26, 4423-4432. [CrossRef] 
170. Fenske, S.; Mader, R.; Scharr, A.; Paparizos, C.; Cao-Ehlker, X.; Michalakis, S.; Shaltiel, L.; Weidinger, M.; Stieber, J.; Feil, S.; et al. HCN3 Contributes to the Ventricular Action Potential Waveform in the Murine Heart. Circ. Res. 2011, 109, 1015-1023. [CrossRef] [PubMed]

171. Zobeiri, M.; Chaudhary, R.; Blaich, A.; Rottmann, M.; Herrmann, S.; Meuth, P.; Bista, P.; Kanyshkova, T.; Lüttjohann, A.; Narayanan, V.; et al. The Hyperpolarization-Activated HCN4 Channel is Important for Proper Maintenance of Oscillatory Activity in the Thalamocortical System. Cereb. Cortex 2019, 29, 2291-2304. [CrossRef] [PubMed]

172. Chaplan, S.R.; Guo, H.-Q.; Lee, D.H.; Luo, L.; Liu, C.; Kuei, C.; Velumian, A.A.; Butler, M.P.; Brown, S.M.; Dubin, A.E. Neuronal Hyperpolarization-Activated Pacemaker Channels Drive Neuropathic Pain. J. Neurosci. 2003, 23, 1169-1178. [CrossRef] [PubMed]

173. Yao, H.; Donnelly, D.F.; Ma, C.; LaMotte, R.H. Upregulation of the Hyperpolarization-Activated Cation Current after Chronic Compression of the Dorsal Root Ganglion. J. Neurosci. 2003, 23, 2069-2074. [CrossRef] [PubMed]

174. Resta, F.; Micheli, L.; Laurino, A.; Spinelli, V.; Mello, T.; Sartiani, L.; Di Cesare Mannelli, L.; Cerbai, E.; Ghelardini, C.; Romanelli, M.N.; et al. Selective HCN1 block as a strategy to control oxaliplatin-induced neuropathy. Neuropharmacology 2018, 131, 403-413. [CrossRef] [PubMed]

175. Weng, X.; Smith, T.; Sathish, J.; Djouhri, L. Chronic inflammatory pain is associated with increased excitability and hyperpolarization-activated current (Ih) in C-but not A $\delta$-nociceptors. Pain. 2012, 153, 900. [CrossRef]

176. Jiang, Y.-Q.; Xing, G.-G.; Wang, S.-L.; Tu, H.-Y.; Chi, Y.-N.; Li, J.; Liu, F.-Y.; Han, J.-S.; Wan, Y. Axonal accumulation of hyperpolarization-activated cyclic nucleotide-gated cation channels contributes to mechanical allodynia after peripheral nerve injury in rat. Pain. 2008, 137, 495-506. [CrossRef]

177. Papp, I.; Holló, K.; Antal, M. Plasticity of hyperpolarization-activated and cyclic nucleotid-gated cation channel subunit 2 expression in the spinal dorsal horn in inflammatory pain. Eur. J. Neurosci. 2010, 32, 1193-1201. [CrossRef]

178. Acosta, C.; McMullan, S.; Djouhri, L.; Gao, L.; Watkins, R.; Berry, C.; Dempsey, K.; Lawson, S.N. HCN1 and HCN2 in Rat DRG neurons: Levels in nociceptors and non-nociceptors, NT3-dependence and influence of CFA-induced skin inflammation on HCN2 and NT3 expression. PLoS ONE 2012, 7, e50442. [CrossRef]

179. Schnorr, S.; Eberhardt, M.; Kistner, K.; Rajab, H.; Käer, J.; Hess, A.; Reeh, P.; Ludwig, A.; Herrmann, S. HCN2 channels account for mechanical (but not heat) hyperalgesia during long-standing inflammation. Pain. 2014, 155, 1079. [CrossRef]

180. Tsantoulas, C.; Laínez, S.; Wong, S.; Mehta, I.; Vilar, B.; McNaughton, P.A. Hyperpolarization-activated cyclic nucleotide-gated 2 (HCN2) ion channels drive pain in mouse models of diabetic neuropathy. Sci. Transl. Med. 2017, 9, eaam6072. [CrossRef] [PubMed]

181. Herrmann, S.; Rajab, H.; Christ, I.; Schirdewahn, C.; Höfler, D.; Fischer, M.J.M.; Bruno, A.; Fenske, S.; Gruner, C.; Kramer, F.; et al. Protein kinase A regulates inflammatory pain sensitization by modulating HCN2 channel activity in nociceptive sensory neurons. Pain. 2017, 158, 2012. [CrossRef] [PubMed]

182. Emery, E.C.; Young, G.T.; Berrocoso, E.M.; Chen, L.; McNaughton, P.A. HCN2 ion channels play a central role in inflammatory and neuropathic pain. Science 2011, 333, 1462-1466. [CrossRef] [PubMed]

183. Herrmann, S.; Schnorr, S.; Ludwig, A. HCN channels-modulators of cardiac and neuronal excitability. Int. J. Mol. Sci. 2015, 16, 1429-1447. [CrossRef] [PubMed]

184. Emery, E.C.; Young, G.T.; McNaughton, P.A. HCN2 ion channels: An emerging role as the pacemakers of pain. Trends Pharmacol. Sci. 2012, 33, 456-463. [CrossRef] [PubMed]

185. Lee, M.C.; Bond, S.; Wheeler, D.; Scholtes, I.; Armstrong, G.; McNaughton, P.; Menon, D. A randomised, double blind, placebo-controlled crossover trial of the influence of the HCN channel blocker ivabradine in a healthy volunteer pain model: An enriched population trial. Pain 2019. [CrossRef] [PubMed]

(C) 2019 by the authors. Licensee MDPI, Basel, Switzerland. This article is an open access article distributed under the terms and conditions of the Creative Commons Attribution (CC BY) license (http://creativecommons.org/licenses/by/4.0/). 